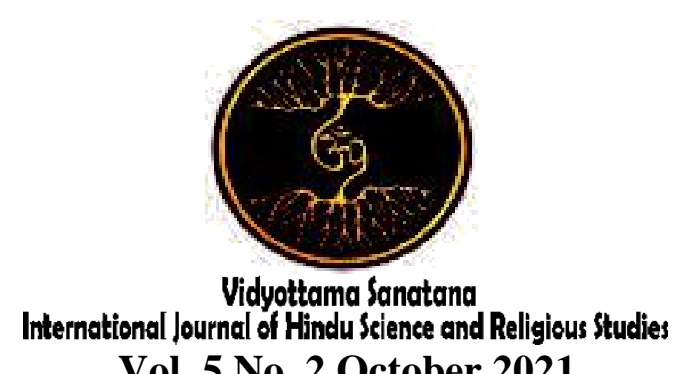

Vol. 5 No. 2 October 2021

\title{
THE SUMMANG SALAK MARRIAGE HELD BY HINDU KAHARINGAN DAYAKS IN SOUTH BARITO
}

\author{
By \\ Derson $^{1}$, I Gede Dharman Gunawan ${ }^{2}$ \\ ${ }^{12}$ Institut Agama Hindu Negeri Tampung Penyang Palangka Raya \\ Email: ${ }^{1}$ tjderson@gmail.com, ${ }^{2}$ dharman.gunawan@gmail.com
}

\begin{tabular}{|l|l|l|}
\hline Received: July 9, 2021 & Accepted: July 12, 2021 & Published: October 31, 2021 \\
\hline
\end{tabular}

\begin{abstract}
Marriage is an inner and outer bond between a man and a woman who will get married. It must get permission from both parents. It also happens on Summang Salak marriage. Along with the development of the era, Summang Salak is almost extinct and it has never been done again by the Hindu Kaharingan Dayaks of South Barito. It is because this kind of marriage is considered bad and needs to be avoided. In addition, it contradicts traditional and religious norms. Summang Salak is a marriage that results from being pregnant outside of marriage and they have a very close family lineage. It used to be very popular among Dayaks because they believed that it would have an impact, both on the descendant and on the people around it. There would be penalty for those who violated and made problems. They were fined and carried out some rituals to purify the area so that everyone would be free from obstacles and calamities. There are four things happened if Summang Salak is carried out without some customary processes and rituals, such as (1) being attacked by sarit sampat or disease outbreaks, (2) being hit by various disasters, (3) rice fields or agriculture are wiped out by pests on a large scale, resulting in crop failure and (4) fruit crops will not be ripe (ore walang) properly.

Keywords: Summang Salak marriage, Hindu Kaharingan
\end{abstract}




\section{INTRODUCTION}

Hindu Kaharingan people always adhere to the rules of national law (government) and traditional law (adat) in carrying out marriage. However, many young people have lived together before marriage in one house without knowing and understanding their family tree. They also have not been legally married, whereas in the teachings of religion, custom and law as a government, it is very contradictory. Every person who wants to get married must fulfill several terms and conditions. The marriage is permitted if a man has reached the age of 25 and a woman has reached the age of 17. It must also be known by both parents, legalized by religious, customary and government institutions. As a consequence of living together before marriage, the couple often faces problems. Those are not only faced by them, but also their families and their communities. One of the biggest problems would be faced by the woman who is pregnant and gives birth outside of marriage. According to the belief of Hindu Kaharingan Dayak people this problem is considered bad marriage because it can affect this couple and the environment around them, such as giving birth to a child in abnormal conditions, creating unpleasant atmosphere around the village and preventing the fruits from being ripe (ore walang).

Epistemologically, Summang Salak is derived from the Dayak language of South Barito, namely summang and salak. "Sumang" means incompatible and it shows that a marriage which is carried out still has one lineage or one blood tie. According to the belief of Dayaks, it should be avoided as much as possible. Meanwhile, "salak" means wrong or prohibition. Dayaks believe that if this kind of marriage is still carried out, it will cause undesirable effects, such as giving birth to abnormal children or mental disabilities, being attacked by various diseases and various kinds of disasters. It also make rice harvesting unsuccessful because of being wiped out by pests and fruit will not be ripe.
It can be concluded that the definition of Summang Salak is a marriage that occurs because it is caused by the relationship between a man and a woman who still have close family or one lineage. Moreover, the woman has given birth to a child outside of marriage and does not carry out a legal marriage, both in religion, tradition, as well as government law.

\section{METHODS}

This type of research is qualitative research. In this study, a qualitative approach that emphasizes the meaning, reasoning, definition of a particular situation, examines more things related to everyday life (Iskandar, 2009:11). This study took the research location in South Barito Regency, Central Kalimantan Province. The interesting thing in this research is related to the existence of the Summang Salak marriage which is almost extinct and has never been done again by the Hindu Kaharingan Dayak Dusun of Barito Selatan Hamlet, because this kind of marriage is a marriage that is considered bad and needs to be avoided because it contradicts traditional and religious norms. So in the research carried out in the Hindu Kaharingan Community of Dayak Dusun in South Barito, it is more researching things related to daily life, especially related to the Summang Salak marriage.

\section{RESULT AND DISCUSSIONS \\ 3.1 Marriages According to Panaturan}

Marriage will occur when both parties are on the page and there are no big problems. In Indonesia's Law No.1 of 1974 on Marriage, Article 1 states that marriage is an inner and outer bond between a man and a woman as husband and wife with the aim of forming a happy and eternal family based on the One Godhead. In other words, this article shows that a marriage means an inner and outer bond formed by a man and a woman who are getting married. It must have the permission of both parents, a marriage may not be carried out due to 
coercion or influence of other people. This is to avoid estrangement after establishing a married life because a success in marriage includes loving each other, cooperating with each other, complementing each other and working hand in hand in every household activity.

According to Hadikusuma (2005: 87), the term "marriage" is derived from the word "kawin" then it is given the prefix "per" and the suffix " $a n$ ", so that it becomes "perkawinan". The prefix "per" means celebration of the marriage. In addition, the term "marriage" has similar word to "pernikahan". It is derived from Arabic and it is often associated with the word "akad" which means promise in the sense of an agreement between a man and a woman as husband and wife. According to the concept of Hindu Kaharingan teachings as stated in the Book of Panaturan (2002), it is hoped that marriage can give birth to descendant who can save their parents or ancestors. The following is an excerpt from Panaturan, Article 20, Verse 9, 11 and 12 "Kameluh Putak Bulau Janjulen Karangan Limut Batu Kamasan Tambun"

\section{Verse 9:}

Basa Kareh,huang ampin tamparan daha ije manjadi bereng uluh kalunen hete atun kajadian ije pangkasulak,jete ije inyewut bagare Lumpuk Matam Limbahie harun ie kajadian tinai manjadi Biti Bereng isi,daha,tulang uhat tuntang pupus bulu.

\section{Meaning:}

It is because when the blood becomes the human body, there is the very first occurrence called "Lumpuk Mata", then it becomes the body, blood, bones, tendons, hair and eyes, which is the shape of the body.

\section{Verse 11:}

Huang katika jete kea ie nukii naharungking bahinge mandehen riwute ije manjadi Aseng panjang tuntang palus atun pahalingei bite umba je jete nyewut Hambaruan.

\section{Meaning:}

At that time he also said that in fact he was living with Himself. He was in the form of a shadow of the holy light of Ranying Hatalla which become one with him, and in fact that in life was called Hambaruan.

\section{Verse 12:}

Kalute peteh Ranying Hatalla hajamban umba Raja Uju Hakanduang ije Inyampaie Umba Manyamei Tunggal Garing Janjahunan Laut,palus ie mahaga bua-buah kakare asi Tuntang kahandak ije i-ath tinai huang pambelum Pantai Danum Kalunen tumun jalae tesek, kalute kea jalae buli nanturung Ranying Hatalla.

\section{Meaning:}

That was the message of Ranying Hatalla through King Uju Hakanduang conveyed to Manyamei Tunggul Garing Janjalunan Laut and he kept all the blessings of love and wishes well arranged by Ranying Hatalla to him, which would later be arranged again in worldly life, as in the beginning, as well he reunited with Ranying Hatalla. (MBHK, 2002)

Based on the points explained in the Book of Panaturan above, humans as social beings have limitations and they always need the presence of other people as friends in which an ideal woman is created to complete a man's life who is mature enough to be tied in a marriage. Marriage is really a bond between husband and wife, based on having mutual love, helping each other, sharing joys and sorrows. A person who has led a household life is said to be an adult in which the woman is called a mother and the man is called a father. Likewise the matter of property, it is no longer called "mine" or 
"yours" but it is "ours". Marriage does not only have religious values, but also has psychological and sociological values. Psychology means a science that studies human behavior or psychological symptoms and human actions in general in connection with marriage. 1) Marriage is a guidance and demand for human mental attitude that runs throughout life, 2) Marriage is a change in mental attitude, namely from being given to giving and from being ordered to being ruled (Anonymous, 2001: 37). Sociology means a science that studies the nature of human life in society in its position as a member of society who has been bound by marriage. Marriage is not a mere civil agreement but a lifelong agreement between the humans and their belief in God.

\subsection{The Meaning of Summang Salak}

According to the customs of Dayak tribe in Pararapak Village, marriages must be carried out legally, either through customary law, religious or government law which is called the Marriage Law. Without customary, religious and government law, it would not be able to take place or illegitimate. The marriage law for Dayak tribe of Hindu Kaharingan, South Barito Regency, Central Kalimantan is not coercive, but can be accepted and obeyed by the surrounding community. Marriage is said to be valid if the bride and groom or both parties love each other by getting the blessings from their parents and their respective families. The marriage should be based on to the religion they believe, without opposing the religious norms, customary and government norms. If a marriage violates the norms or it is not in accordance with the prevailing religious and customary norms, it will have several impacts on both parties and on the surrounding environment.

The Summang Salak marriage at the beginning have already existed since the era of the Dayak ancestors and this marriage is very existent because it carried out by the Dayak tribe of the Hindu Kaharingan in the
South Barito, Central Kalimantan. This kind of marriage is not like other common marriages because it is a forced marriage which is not appropriate because it contradicts the prevailing religious teachings and customs. It occurs because a young man and a young woman have marital relationship without marriage and it results in the woman giving birth to a child. Additionally the couple also still have close family ties or one lineage. When carrying out the marriage, it is not done legally because it is against religious, customary and the government law. In other words, this kind of marriage is very inappropriate to do because it will have an impact on the children of that couple and the community around the area where they live. The Summang Salak marriage is not an ordinary marriage that can be done just like the other marriages because it needs some customary ritual requirements. If this marriage is continued without applying customary law, it can cause disasters that can harm oneself and others. There are 4 (four) impacts that can be caused if this marriage is carried out, such as (1) being attacked by sarit sampat or disease outbreaks, (2) being hit by various calamities, (3) rice fields or agriculture are wiped out by pests on a large scale, resulting in crop failure and (4) fruit crops will not be ripe (ore walang) properly.

Summang Salak marriage carried out by the Hindu Kaharingan Dayaks in South Barito Regency is highly believed because according to a belief, it does not only have a religious meaning which is not real, but also have a real impact on the descendant and on the society around it. The steps of Summang Salak marriage is unlike the other common marriages because in this marriage there are some conditions that must be fulfilled especially the process of paying for customary law, facilities and carrying out rituals for cleaning the village. Dayaks believe that it is a marriage that have a very bad impression and needs cleaning or purification of the village that is affected by lahing liha (the atmosphere of village becomes hot). The following is the spell or 
mantra uttered by traditional mantir or wadian summang when Basaki Bakapilah using one local chicken egg and pig blood.

Ade maringin maroe ngunau karingin telui tu lei welum pakan koree dan awing aweh koree baka welum baka pakan. Tu ku nyaki milah tundru pee nu, ade tuah rajaki koree huang welum pakan hallu nyimpun harta benda ade laa anak bua koree. Ku nyaki milah lapak pee nu ade orro nike sial kawe pali. Tu ku nyaki milah balagasing onggon ade orro neke kadaat kadaai awe tau jari mati jawoh. Ku nyaki milah balagasing huang ade korre baruee tau baumur amauu.

Ku nyaki milah lepak tangga saii ade nyaput re buon, ade nyilak neke masam persoalan welum ampin tuah rajaki. Ku nyaki milah takalo nuu ade halu ampin kondree baruee ngawawi awing awe lukun penu kajujur.Ku nyaki milah lapak sanan nu ade nugo tuah rajaki umur amauu. Ku nyaki milah hiku nu ade nampi neke reten ampin pulu punggau neke konree baruee.

Tu ku nyaki milah dada nu ade tau namba tuah rajaki moo nu gugup moo nu gaer. Tu ku nyaki milah likut nu ade nu nyalikut nike sial pali. Tu ku nyaki milah mooh paluke butu balokok ade mua tarung ka buon baruee welum tatau sanang.

\section{Meaning:}

I purify the tip of your toes, a group of abundant fortunes both of you in your life can immediately accumulate wealth for your children. I clean the back of your soles so that you are far from infertility. I purify the outside of your ankles so that you are away from bad things that can lead to death. I purify the inside of your ankles so that you both may have long life.
I purify your knees so that you can the work with full honesty. I purify the left palms of your hands for you to put aside all kinds of problems that concern life.

From the explanation above, the implementation of Salak Summang is a marriage that has religious values because it must follow the traditional ritual procedures. This kind of marriage is very rare and hardly found because it is very imprecise and unfavorable marriage. This kind of marriage is a marriage in a state of necessity because the couple still has very close family lineages, such as uncle, aunt, nephew and cousins. As an illustration, when a woman who live together with a man before a legal marriage gets pregnant and give birth to a child. However, according to the belief of Hindu Kaharingan people, South Barito regency, if the marriage is carried out, they must do the traditional ritual of cleaning the village first led by traditional, religious and community leaders. It must be done to make the atmosphere of the village (laling liha tumpuk natat) back to normal no more calamities happen to both parties and other people.

\subsection{Customary Law of Muja Sumbang in Summang Salak Marriage}

In the implementation of Summang Salak, there is also another series that must be done called muja summang. It is a ceremony that is carried out after the ritual is held. Muja Summang is obligatory because it aims to cleanse the bride and groom as a result of the laing rihat pandrit langan that violates religious and customary norms. Meanwhile, the levels of summang (error level) can be categorized into two. First, (1) summang is considered light, such as family relationships are not suitable or there is a very close family relationship. It only needs palis summang or pamadik tutur (reversing family ties). Then (2) summang that is considered as severe as being pregnant outside of 
marriage, is obliged to hold a muja summang ceremony which is adored by wadian or Summang traditional leaders. There are 4 (four) types of customary fines, namely (1) Palome poo koroi, besi mahing talu tokeng means to reduce the anger of the woman's family in the amount of 20 kiping, (2) Rapus tampalang (Mantir law) needs 20 kiping, (3) Pamadik tutur (reversing the family relationship) is 10 kiping and (4) Tammai Wadian Summang (sesari ) is related to the willingnesses given by those who have the event as well as some of the offerings that have been prepared. The value of one kiping is about IDR 50,000.

There are some of the customary law facilities (parabea) and infrastructure that must be fulfilled if Summang Salak is carried out, namely 1) Isa bahalai pahapau summang (a long sarong for the roof where the ritual is performed, 2) Isa bahalai (a long sarong) which is used to carry a statue (pangipis sampatung jalang) as a symbol of the bride and groom who will do the rituals. 3) Manu jagau kampung ruweh kikui (two local chickens to be sacrificed), 4) Isa kaikui iwek (a pig) for offering animals and its blood for saki pilah to remove all bad luck or hunch and 5) Kanen kuta (offering) bane (lemang), katupat, katupat lapat, cucur, gagatas and eight other pastries.

\section{CONCLUSION}

The meaning contained in Summang Salak marriage is as a form of sradha and bhakti to God and ancestors. It is also a form of solidarity with the surrounding community. It is because this kind of marriage should be avoided and Kaharingan Hindu community are very obedient and believe in the customary and religious norms, especially in South Barito. This kind of marriage is highly undesirable, except in forced circumstances such as pregnancy out of marriage. However, if the community does not comply and violate the rules set and still perform Summang Salak marriage without going through the process of customary law and village cleaning rituals, then they should be ready to accept the risks and bear the consequences, such as eating in dulang babi (a special container to put pig food) and is obliged to pay fines (jipen) customary law that has been determined. They also need to do rituals of purification or cleaning the village that is led by some customary, religious figures, and community leaders affected by disasters as a result of violating customary and religious norms. By performing the ritual of cleaning or purifying the village, then the community's life becomes more calm and normal as usual.

\section{REFERENCES}

Agung, I. G. A. I. (2018). The Challenge Faced by Hindu Women in Doing Their Swadharma in the Midst of

Modernisation. Vidyottama

Sanatana: International

Journal of Hindu Science and Religious Studies, 2(1), 99-108.

Anonymous. (2002). Panaturan. Majelis

Besar Agama Hindu

Kaharingan Pusat Palangka Raya.

Karolina, Anita. (2004). Peran Hukum Adat Dalam Pelaksanaan

Perkawinan Dayak Dusun Di

Desa Pararapak Kecamatan Dusun Selatan Kabupaten Barito selatan : Skripsi IAHNTP Palangka Raya

Bakker. (1984). Filsafat Kebudayaan Sebuah Pengantar. Yogyakarta : Kanisius.

Daeng, Hans. J. (2005). Manusia, Kebudayaan dan Lingkungan Tinjauan Antropologis. Yogyakarta: Pustaka Pelajar Offset.

Gelgel, I Putu. (2013). Hukum Perkawinan

Hindu, Denpasar: PPs UNHI Percetakan Bali

Hadikusuma Hilman. (2003). Hukum Perkawinan Indonesia Menurut Pandangan Hukum Adat dan Hukum Agama. Bandung: Mandar Maju. 
Herwandi. (2015). Hukum Perkawinan Umat Hindu Kaharingan Di Desa Tewang Manyangen Kecamatan Tewang Sangalang Garing Kabupaten Katingan. Tesis PPs IAHN-TP Palangka Raya.

Iskandar. (2009). Metode Penelitian Kualitatif. Jakarta: Gaung Persada.

Kolip Usman, dkk. (2011). Pengantar Sosiologi Pemahaman Fakta Dan Gejala Permasalahan Sosial : Teori Aplikasi Dan Pemecahan. Jakarta : Kencana.

Riwut, Tjilik. (2003). Maneser Panatau Tatu Hiang, Menyelami Kekayaan Leluhur, Pusaka Lima : Palangka Raya.

Sirman Dahwal. (2017). Perbandingan Hukum Perkawinan. Bandung: Mandar Maju.

Soares, F., \& Sudarsana, I. K. (2018). Religious Harmony Among Senior High School Students Multicultural Education Case Study in the Cova-Lima District of East Timor. Vidyottama Sanatana: International Journal of Hindu Science and Religious Studies, 2(1), 154-162.

Suwito,dkk. (2012). Peranan Hukum Adat Dalam Pelaksanaan

Perkawinan Dayak Dusun di Desa Pararapak Kecamatan Dusun Selatan Kabupaten Barito Selatan. Penelitian IAHN Tampung Penyang : Palangkaraya.

Surayin, Ida Ayu Putu. (2004). Dewa Yadnya. Surabaya: Paramita.

Sugiyo. (2006). Tata Cara Upacara Perkawinan Menurut Agama Hindu Kaharingan Suku Dayak Dusun Bayan di Kecamatan Tewei Tengah. Penelitian: Palangkaraya.
Sztompka, Piotr. (2010). Sosiologi Perubahan Sosial. Jakarta: Prenada.

Tim Penyusun. (2002). Panaturan. Majelis Besar Agama Hindu Kaharingan: Palangka Raya.

Tim Penyusun. (2009). Hukum Adat Dayak Dusun Barito Selatan. Buntok: Barito Selatan.

Undang-Undang Republik Indonesia Nomor 1 Tahun 1974 Tentang Perkawinan. Presiden Republik Indonesia. Jakarta. 